\title{
DNA damage and induction of apoptosis in pancreatic cancer cells by a new dinuclear bis(triazacyclonane) copper complex
}

\author{
Diego Montagner ${ }^{\mathrm{a}, 1}$, Valentina Gandin ${ }^{\mathrm{b}, 1}$, Cristina Marzano ${ }^{\mathrm{b}}$, Andrea Erxleben ${ }^{\mathrm{a}, *}$ \\ a School of Chemistry, National University of Ireland, Galway, Ireland \\ b Dipartimento di Scienze del Farmaco, Universita' degli Studi di Padova, Padova, Italy
}

\section{A R T I C L E I N F O}

\section{Article history:}

Received 3 October 2014

Received in revised form 15 January 2015

Accepted 18 January 2015

Available online 26 January 2015

\section{Keywords:}

Copper

Cytotoxicity

DNA damage

Metallodrugs

\begin{abstract}
A B S T R A C T
The dinuclear copper(II) complex $\left[\mathrm{Cu}_{2}\{\mathrm{bcmp}(-\mathrm{H})\}(\mu-\mathrm{OH})\right]\left(\mathrm{NO}_{3}\right)_{2} \cdot \mathrm{H}_{2} \mathrm{O}(\mathbf{1}$, bcmp $=2,6$-bis $(1,4,7$-triazacyclonon1-ylmethyl)-4-methylphenol) has been synthesized and characterized by electrospray ionization mass spectrometry, potentiometric titration and cyclovoltammetry. The X-ray structure of the analogous perchlorate salt $\left[\mathrm{Cu}_{2}\{\mathrm{bcmp}(-\mathrm{H})\}(\mu-\mathrm{OH})\right]\left(\mathrm{ClO}_{4}\right)_{2} \cdot 2.5 \mathrm{H}_{2} \mathrm{O}(2)$ was determined. Cytotoxicity studies showed very promising activity of 1 against various pancreatic tumor cell lines with $\mathrm{IC}_{50}$ values comparable or even lower than those of cisplatin. The Cu complex displayed low toxicity against a human non-tumor cell line (HEK 293) demonstrating selectivity for cancer cells. 1 converts supercoiled pUC19 plasmid DNA into the nicked form at micromolar concentrations in the absence of added reductants. A detailed kinetic study on the hydrolysis of the DNA model bis(2,4-dinitrophenyl) phosphate (BDNPP) has been performed. 1 hydrolyses BDNPP with a second order rate constant of $0.047 \mathrm{M} \mathrm{s}^{-1}$ at pH 8 and $40^{\circ} \mathrm{C}$. Finally, single cell electrophoresis (comet assay) and fluorescence microscopy analysis showed that 1 interacts with cellular DNA and induces apoptotic cell death of Capan-1 pancreatic cancer cells. Western blotting analysis indicated that the $\mathrm{Cu}$ complex activates the p53 dependent pathway of apoptosis.
\end{abstract}

\section{Introduction}

Copper is an essential element for most aerobic organisms. Employed as a structural and catalytic cofactor it is involved in many biological pathways [1-3]. In the search for new anticancer metallodrugs that can overcome the limitations of routinely used Pt drugs such as severe side effects, toxicity and inherent and acquired resistance, there is growing interest in biometals like $\mathrm{Cu}$, as they are biocompatible and less toxic that non-endogenous heavy metals. Furthermore, $\mathrm{Cu}$ is an interesting candidate for the treatment of cancers because of its bioavailability and the observation of increased Cu levels in cancer tissue [4].

The importance of $\mathrm{Cu}$ in anticancer therapy is demonstrated by the ever increasing group of cytotoxic Cu complexes described in the literature, with the number of papers reported in 2012 being eight times greater than in 2008 [5,6]. Several synthetic Cu complexes have been found to be active both in vitro and in vivo [4].

Cytotoxic $\mathrm{Cu}(\mathrm{II})$ complexes often show DNA cleavage activity $[4,7,8]$, suggesting a connection between these two properties. The mechanism of Cu complex-induced DNA strand breaks often involves the formation of reactive oxygen species (ROS) through the Fenton reaction following the reduction of $\mathrm{Cu}(\mathrm{II})$ to $\mathrm{Cu}(\mathrm{I})$ by biological reducing agents such as

\footnotetext{
* Corresponding author. Tel.: +35391 492483; fax: +35391495576.

E-mail address: andrea.erxleben@nuigalway.ie (A. Erxleben).

1 Joint first authors.
}

ascorbic acid. Metal-catalyzed hydrolysis of the phosphodiester backbone of DNA, however, is also an attractive strategy for damaging tumor cell DNA irreversibly, because the mechanism does not require the addition of external agents. Furthermore, hydrolytic metallonucleases may find additional applications in molecular biology as substitutes for restriction enzymes or footprinting agents or as biomimetic systems helping to elucidate the mechanism of action of natural nucleases [9]. While natural enzymes have an active site with one or more metal ions surrounded by amino acids that are essential for the catalytic processes, in artificial nucleases the protein matrix is replaced by simple organic ligands.

In this paper we report the synthesis and full characterization of a novel dicopper(II) complex with a binucleating ligand containing a phenol scaffold and two triaza crown binding sites. The metallonuclease properties of the $\mathrm{Cu}$ complex were investigated in isolated DNA and the effects of DNA cleavage on cancer cell growth were assessed in Capan-1 pancreatic cancer cells.

\section{Experimental}

\subsection{Materials and instrumentation}

$\mathrm{Cu}\left(\mathrm{NO}_{3}\right)_{2} \cdot 2.5 \mathrm{H}_{2} \mathrm{O}$ was purchased from TCl Europe and used as supplied. All the other chemicals and solvents were of analytical or spectroscopic grade, obtained from commercial sources and used without further purification. Deuterated solvents were obtained from Apollo 
Scientific. MTT (3-(4,5-dimethylthiazol-2-yl)-2,5-diphenyltetrazolium bromide) and cisplatin were obtained from Sigma Chemical Co, St. Louis, USA. Bis(2,4-dinitrophenyl) phosphate (BDNPP) was prepared according to the literature [10]. 2,6-bis(1,4,7-triazacyclonon-1-ylmethyl)4-methylphenol was synthesized by a modified literature procedure [11] as recently described by us [12].

The $\mathrm{pD}$ values of $\mathrm{D}_{2} \mathrm{O}$ solutions were adjusted using concentrated $\mathrm{DNO}_{3}$ and NaOD. UV/Vis measurements were carried out on a Varian Cary 50 scan spectrophotometer coupled to a Grant thermostated water circulation bath. Elemental analyses (carbon, hydrogen and nitrogen) were performed with a PerkinElmer 2400 series II analyzer. Electrospray ionization (ESI) mass spectra were recorded with a Waters LCT Premier XE Spectrometer. Electrochemical measurements were performed in $50 \mathrm{mM}$ phosphate buffer ( $\mathrm{pH} \mathrm{7)}$ at room temperature using a CH Instruments 620 series potentiostat, coupled to an electrochemical cell containing an $\mathrm{Ag} / \mathrm{AgCl}$ reference electrode (Bioanalytical Systems), a platinum foil counter electrode (Goodfellow) and a $3 \mathrm{~mm}$ glassy carbon working electrode (Goodfellow). Potentials are quoted versus the $\mathrm{Ag} / \mathrm{AgCl}$ reference electrode.

\subsection{Potentiometric titration}

An aqueous solution of $\mathbf{1}(1 \mathrm{mM}, 50 \mathrm{~mL})$ was titrated with a standardized $0.1 \mathrm{M} \mathrm{NaOH}$ solution at $25^{\circ} \mathrm{C}$. The ionic strength was maintained at $0.1 \mathrm{M}$ with $\mathrm{KNO}_{3}$. $\mathrm{pH}$ values were measured with a Jenway 3510 pH meter fitted with a Refex Sensor Ltd. EC-1910-11 glass electrode. The program HYPERQUAD was used to calculate the deprotonation constant from the titration data [13].

\subsection{UV kinetic measurements}

The hydrolysis rates of BDNPP were measured by monitoring the increase in the visible absorbance at $400 \mathrm{~nm}$ due to the release of 2,4-dinitrophenolate. Rate constants were obtained by the initial rate method ( $<5 \%$ conversion). Concentrations of 2,4-dinitrophenolate were calculated from the extinction coefficients $\left(12,100 \mathrm{M}^{-1} \mathrm{~cm}^{-1}\right.$ for 2,4-dinitrophenolate). Concentrations were corrected for the degree of ionization of 2,4-dinitrophenol at the respective $\mathrm{pH}$ value using $\mathrm{pK}_{\mathrm{a}}$ $(2,4$-dinitrophenol $)=4.0$ [14]. In a typical experiment $15 \mu \mathrm{L}$ of a freshly prepared BDNPP stock solution (5 mM in DMSO) was added to a solution of the metal complex $(1.5 \mathrm{~mL}, 0.25-5 \mathrm{mM})$ at $40^{\circ} \mathrm{C}$. The metal complex solutions were buffered with $50 \mathrm{mM}$ PIPBS (pH 3.5-5), MES ( $\mathrm{pH}$ 5-6.7), HEPES ( $\mathrm{pH} \mathrm{6.8-8.5)} \mathrm{and} \mathrm{CHES} \mathrm{(} \mathrm{pH} 8.5-11.0$ ). The ionic strength was maintained at $0.1 \mathrm{M}$ with $\mathrm{KNO}_{3}$. Cleavage rates were corrected for the spontaneous hydrolysis of the substrate [10]. The kinetic $\mathrm{pK}_{\mathrm{a}}$ value was determined by fitting the data to

$\mathrm{k}_{\mathrm{obs}}=\left(\mathrm{k}_{\mathrm{H} 2 \mathrm{O}}\left[\mathrm{H}^{+}\right]+\mathrm{k}_{\mathrm{OH}} \mathrm{K}_{\mathrm{a}}\right) /\left(\mathrm{K}_{\mathrm{a}}+\left[\mathrm{H}^{+}\right]\right)$.

To determine the solvent deuterium isotope effect, analogous kinetic experiments were performed in $99.9 \% \mathrm{D}_{2} \mathrm{O}$. The correction $\mathrm{pD}=$ $\mathrm{pH}_{\text {measured }}+0.4$ was applied to the $\mathrm{pH}$ meter readings $[15,16]$. Kinetic runs were run in duplicate to give a reproducibility of $\pm 15 \%$.

\subsection{X-ray analysis}

Crystal data for compound $\mathbf{2}$ were collected at room temperature on an Agilent (formerly OxfordDiffraction) Xcalibur CCD diffractometer using graphite-monochromated Mo- $K_{\alpha}$ radiation $(\lambda=0.71069 \AA)$ [17]. The structure was solved by direct methods and subsequent Fourier syntheses and refined by full-matrix least squares on $\mathrm{F}^{2}$ using SHELXS-97, SHELXL-97 [18-20] and Oscail [21]. The scattering factors were those given in the SHELXL program. Hydrogen atoms except those for the water molecules of crystallization were generated geometrically and refined as riding atoms with isotropic displacement factors equivalent to 1.2 times those of the atom to which they were attached ( 1.5 for methyl groups). The asymmetric unit of $\mathbf{2}$ that crystallized in the triclinic space group P1 contains two crystallographically independent complex cations. A MISSYM check $[22,23]$ was carried out to rule out any missed symmetry. The Flack's parameter [24] converged to $x=0.65(2)$ indicating racemic twinning, which was taken into account during the final cycles of least squares refinement using the twin law $-1000-1000-12$. Graphics were produced with ORTEX [25]. Crystallographic data and details of refinement are reported in Table S1.

\subsection{DNA plasmid cleavage}

pUC19 DNA cleavage activity of compound $\mathbf{1}$ was evaluated by agarose gel electrophoresis. Plasmid pUC19 DNA ( $1 \mu \mathrm{g} / \mu \mathrm{L})$ was incubated with increasing concentration (range $5-50 \mu \mathrm{M}$ ) of 1 in Tris buffer ( $50 \mathrm{mM}$ Tris, $18 \mathrm{mM} \mathrm{NaCl}, \mathrm{pH} 8.2$ ) at $37^{\circ} \mathrm{C}$ for $3 \mathrm{~h}$ in the dark. The reaction was quenched by the addition of $3 \mu \mathrm{L}$ of loading buffer $(0.25 \%$ bromophenol blue and $30 \%$ glycerol) and samples were loaded onto a $1 \%$ agarose gel in TBE buffer ( $89 \mathrm{mM}$ Tris, $89 \mathrm{mM}$ boric acid, $2 \mathrm{mM}$ EDTA, pH 8.2). The gels were subjected to electrophoresis for $4 \mathrm{~h}$ at $50 \mathrm{~V}$, followed by staining with $0.5 \mu \mathrm{g} / \mathrm{mL}$ ethidium bromide overnight. Gel bands were visualized using a UV transilluminator and photographed using an Olympus digital camera.

\subsection{Experiments with cultured human cells}

Compound 1 was dissolved in DMSO just before the experiment and a calculated amount of drug solution was added to the cell growth medium to a final solvent concentration of $0.5 \%$, which had no detectable effect on cell killing. Cisplatin was dissolved in $0.9 \% \mathrm{NaCl}$ solution.

\subsection{Cell cultures}

Human breast (MCF-7), colon (HCT-15), and pancreatic (BXPC3, MIA Paca-2, AsPC-1, Capan-1, PANC-1) carcinoma cell lines along with melanoma (A375) cells and nontransformed embryonic kidney (HEK293) were obtained from American Type Culture Collection (ATCC, Rockville, MD). The human ovarian 2008 cancer cell line was kindly provided by Prof. G. Marverti (Dept. of Biomedical Science of Modena University, Italy). Human cervical carcinoma (A431) cells were kindly provided by Prof. F. Zunino (Division of Experimental Oncology B, Istituto Nazionale dei Tumori, Milan, Italy). Cell lines were maintained in the logarithmic phase at $37^{\circ} \mathrm{C}$ in a $5 \%$ carbon dioxide atmosphere using the following culture media containing $10 \%$ fetal calf serum (Euroclone, Milan, Italy), antibiotics ( 50 units $/ \mathrm{mL}$ penicillin and $50 \mu \mathrm{g} / \mathrm{mL}$ streptomycin) and $2 \mathrm{mM}$ L-glutamine: (i) RPMI-1640 medium (Euroclone) for 2008, MCF-7, HCT-15, A431, AsPC-1 and BxPC3 cells; (ii) F-12 HAM'S (Sigma Chemical Co.) for A549 cells; iii) DMEM (Sigma Chemical Co.) for MIA Paca-2, PANC-1, A375 and HEK293 cells; IMDM (Sigma Chemical Co.) for Capan-1 cells.

\subsection{MTT assay}

The growth inhibitory effect towards tumor cells was evaluated by means of the MTT assay [26]. Briefly, (3-8) $\times 10^{3}$ cells/well, dependent upon the growth characteristics of the cell line, were seeded in 96-well microplates in growth medium $(100 \mu \mathrm{L})$. After $24 \mathrm{~h}$, the medium was removed and replaced with fresh media containing the compound to be studied at the appropriate concentration. Triplicate cultures were established for each treatment. After $72 \mathrm{~h}$, each well was treated with $10 \mu \mathrm{L}$ of a $5 \mathrm{mg} / \mathrm{mL}$ MTT saline solution, and following $5 \mathrm{~h}$ of incubation, $100 \mu \mathrm{L}$ of a SDS solution in $0.01 \mathrm{M} \mathrm{HCl}$ was added. After an overnight incubation, cell growth inhibition was detected by measuring the absorbance of each well at $570 \mathrm{~nm}$ using a Bio-Rad 680 microplate reader. The mean absorbance for each drug dose was expressed as a percentage of the control untreated well absorbance and plotted vs drug 
concentration. $\mathrm{IC}_{50}$ values, the drug concentrations that reduce the mean absorbance at $570 \mathrm{~nm}$ to $50 \%$ of those in the untreated control wells, were calculated by a four parameter logistic (4-PL) model.

\subsection{Comet assay}

Single-cell gel electrophoresis for detection of DNA damage was performed using the comet assay reagent kit purchased from Trevigen (Trevigen Inc., Gaithersburg, MD, US) according to the manufacturer's instructions. Briefly, Capan-1 $\left(2 \times 10^{5}\right)$ cells were seeded in $25 \mathrm{~cm}^{2}$ flasks in growth medium ( $6 \mathrm{~mL}$ ). After $24 \mathrm{~h}$, cells were incubated for different exposure times ( 6 and $12 \mathrm{~h}$ ) with increasing concentrations of the tested compound. Subsequently, cells were washed twice with cold phosphate buffered saline (PBS), harvested, centrifuged, and resuspended at $1 \times 10^{5} \mathrm{cell} / \mathrm{mL}$ in $1 \%$ low melting point agarose (LMPA, Trevigen). Then $50 \mu \mathrm{L}$ of the cells-LMPA mixture was layered onto frosted microscope slides which were pre-coated with $1 \%$ normal agarose. After the agar had been allowed to set at $4{ }^{\circ} \mathrm{C}$, the slides were immersed in lysis buffer ( $100 \mathrm{mM} \mathrm{Na}_{2}$ EDTA, $2.5 \mathrm{M} \mathrm{NaCl}, 10 \mathrm{mM}$ Tris pH 10.0, and $1 \%$ Triton $\mathrm{X}-100)$ for $1 \mathrm{~h}$ at $4{ }^{\circ} \mathrm{C}$. The slides were then incubated in an alkaline electrophoresis solution ( $1 \mathrm{mM}$ EDTA, $300 \mathrm{mM} \mathrm{NaOH}, \mathrm{pH}>13$ ) at $4{ }^{\circ} \mathrm{C}$ for $40 \mathrm{~min}$, followed by electrophoresis $(1 \mathrm{~V} / \mathrm{cm})$ at $4{ }^{\circ} \mathrm{C}$ for $30 \mathrm{~min}$. The slides were washed three times with neutralization buffer before immersion in absolute ethanol for $20 \mathrm{~min}$. and air-dried at room temperature. The DNA was stained with SYBR Green $(1 \mu \mathrm{g} / \mathrm{mL})$ for $5 \mathrm{~min}$. at $4{ }^{\circ} \mathrm{C}$. A total of 50 comets per slide, randomly captured at a constant depth of the gel, were examined at 40-fold magnification in a fluorescence microscope (Olympus BX41, Milano, Italy; excitation, $495 \mathrm{~nm}$; emission, $521 \mathrm{~nm}$ ) connected through a black and white camera to a computer-based image analysis system. Comets were randomly captured at a constant depth of the gel, avoiding the edges of the gel, occasional dead cells, and superimposed comets. DNA damage was measured as tail length (distance of DNA migration from the middle of the body of the nuclear core) using Cell-F software (Olympus).

\subsection{Hoechst 33258 staining}

Capan-1 cells were seeded into 8-well tissue-culture slides (BD Falcon, Bedford, MA, USA) at $5 \times 10^{4}$ cells/well $\left(0.8 \mathrm{~cm}^{2}\right)$. After $24 \mathrm{~h}$, cells were washed twice with PBS and following 48 and $72 \mathrm{~h}$ of treatment with $\mathrm{IC}_{50}$ doses of the tested compound, cells were stained for $5 \mathrm{~min}$ with $10 \mu \mathrm{g} / \mathrm{mL}$ of Hoechst (2'-(4-hydroxyphenyl)-5-(4-methyl1-piperazinyl)-2,5'-bi-1H-benzimidazole trihydrochloride hydrate, Sigma-Aldrich) in PBS before being examined by fluorescence microscopy (Olympus).

\subsection{Western blot analysis}

About $10^{6}$ Capan- 1 cells were treated for 24 and $48 \mathrm{~h}$ with $\mathrm{IC}_{50}$ doses of the tested compound. Afterwards, cells were harvested, lysed in RIPA buffer ( $1 \%$ NP40, $0.5 \%$ sodium deoxycholate, $0.1 \%$ SDS), and centrifuged at $13,000 \times \mathrm{g}$ for $15 \mathrm{~min}$ at $4^{\circ} \mathrm{C}$. $\beta$-actin was used as a loading control. An equal amount of proteins for each sample was electrophoresed on a $12 \%$ SDS-PAGE and blotted to a nitrocellulose membrane. The membrane was incubated for $1 \mathrm{~h}$ in PBS-Tween 20 (0.05\%) containing 5\% nonfat milk and then at $37^{\circ} \mathrm{C}$ for $1 \mathrm{~h}$ with primary antibodies. The membranes were stained with the corresponding peroxidase-conjugated secondary antibodies for $1 \mathrm{~h}$ at room temperature and detected by ECL according to the manufacturer's protocol (GE).

\subsection{Synthesis of the Cu complexes}

$\left[\mathrm{Cu}_{2}\{\mathrm{bcmp}(-\mathrm{H})\}(\mu-\mathrm{OH})\right]\left(\mathrm{NO}_{3}\right)_{2} \cdot \mathrm{H}_{2} \mathrm{O}(\mathbf{1})$ was prepared by mixing $\mathrm{Cu}\left(\mathrm{NO}_{3}\right)_{2} \cdot 2.5 \mathrm{H}_{2} \mathrm{O}(380 \mathrm{mg}, 2.06 \mathrm{mmol})$, dissolved in $15 \mathrm{~mL}$ of water and a solution of bcmp (402 mg, $1.03 \mathrm{mmol}$ ) in $5 \mathrm{~mL}$ methanol. After adjusting the $\mathrm{pH}$ value to 6.8 with $\mathrm{NaOH}$ the green solution was evaporated using a rotavapor. The residue was dissolved in $15 \mathrm{~mL}$ methanol and filtered. Slow diffusion of diethyl ether into the alcoholic solution afforded green crystals of formula $\left[\mathrm{Cu}_{2}\{\mathrm{bcmp}(-\mathrm{H})\}(\mu-\mathrm{OH})\right]\left(\mathrm{NO}_{3}\right)_{2} \cdot \mathrm{H}_{2} \mathrm{O}$. Yield: $480 \mathrm{mg}(0.71 \mathrm{mmol}, 69 \%)$. Anal. Calcd. (\%) for $\mathrm{C}_{21} \mathrm{H}_{40} \mathrm{~N}_{8} \mathrm{O}_{9} \mathrm{Cu}_{2}$ : C, 37.33; H, 5.96; N, 16.58; found: C, 37.15, H, 5.31; N, 16.88\%. ESI MS (positive ion mode): $\mathrm{m} / \mathrm{z}: 596.11\left[\mathrm{M}-\mathrm{NO}_{3}-\mathrm{H}_{2} \mathrm{O}\right]^{+}$. Crystals of $\left[\mathrm{Cu}_{2}\{\mathrm{bcmp}(-\mathrm{H})\}(\mu-\mathrm{OH})\right]\left(\mathrm{ClO}_{4}\right)_{2} \cdot 2.5 \mathrm{H}_{2} \mathrm{O}$ (2) suitable for X-ray analysis were obtained by slow evaporation ( 5 weeks) of an aqueous solution of $30 \mathrm{mg}$ of $\mathbf{1}$ in the presence of $10.8 \mathrm{mg} \mathrm{NaClO}$. Caution! Although no problems were encountered in this work, transition metal perchlorate complexes are potentially explosive and should be handled with proper precaution.

\section{Results and discussion}

3.1. Synthesis and characterization of $\left[\mathrm{Cu}_{2}\{\mathrm{bcmp}(-\mathrm{H})\}(\mu-\mathrm{OH})\right]\left(\mathrm{NO}_{3}\right)_{2} \cdot \mathrm{H}_{2} \mathrm{O}$ (1) and $\left[\mathrm{Cu}_{2}\{\mathrm{bcmp}(-\mathrm{H})\}(\mu-\mathrm{OH})\right]\left(\mathrm{ClO}_{4}\right)_{2} \cdot 2.5 \mathrm{H}_{2} \mathrm{O}(\mathbf{2})$

In this study, the dinucleating ligand 2,6-bis(1,4,7-triazacyclonon-1ylmethyl)-4-methylphenol (bcmp) with two 9-membered aza-crown binding sites was chosen because of the well-established high affinity of $\mathrm{Cu}^{2+}$ ions for 1,4,7-triazacyclonane (tacn). The logK value for mononuclear $\mathrm{Cu}(\operatorname{tacn})^{2+}$ is 15.5 , suggesting that a highly stable bcmp complex is formed under physiological conditions [27]. Furthermore, Cu complexes of tacn ligands are generally good catalysts for phosphate ester hydrolysis $[28,29]$. The aromatic spacer provides a rigid scaffold for the bimetallic site, while the bridging phenoxy group shields the electrostatic repulsion between the metal ions and holds the two $\mathrm{Cu}^{2+}$ ions in close proximity. We have previously reported a modified synthetic procedure for bcmp [12].

The dinuclear $\mathrm{Cu}(\mathrm{II})$ complex $\left[\mathrm{Cu}_{2}\{\mathrm{bcmp}(-\mathrm{H})\}(\mu-\mathrm{OH})\right]\left(\mathrm{NO}_{3}\right)_{2} \cdot \mathrm{H}_{2} \mathrm{O}$ (1) was prepared by reacting the ligand bcmp with two equivalents of $\mathrm{Cu}\left(\mathrm{NO}_{3}\right)_{2}$ in a methanol/water mixture at $\mathrm{pH} 6.8$ (Chart 1). The complex has been characterized by elemental analyses and ESI mass spectrometry. The latter shows a signal centered at $\mathrm{m} / \mathrm{z}=596.1$ which can be assigned to the isotopomers of $\left[\mathrm{Cu}_{2}\{\mathrm{bcmp}(-\mathrm{H})\}(\mu-\mathrm{OH})\left(\mathrm{NO}_{3}\right)\right]^{+}$ (Fig. S1). $\left[\mathrm{Cu}_{2}\{\mathrm{bcmp}(-\mathrm{H})\}(\mu-\mathrm{OH})\right]\left(\mathrm{ClO}_{4}\right)_{2} \cdot 2.5 \mathrm{H}_{2} \mathrm{O}(2)$ was obtained by recrystallizing complex $\mathbf{1}$ from water in the presence of $\mathrm{NaClO}_{4}$. X-ray suitable crystals of $\mathbf{2}$ were grown by slow evaporation of an aqueous solution at r.t. and the structure is described below.

The potentiometric titration of $\mathbf{1}$ revealed a single deprotonation step with a $\mathrm{pK}_{\mathrm{a}}$ value of $4.69 \pm 0.09$ (Fig. S2). The $\mathrm{pK}_{\mathrm{a}}$ value for the deprotonation of the first of the two terminally bound water ligands in mononuclear $\left[\mathrm{Cu}(\operatorname{tacn})\left(\mathrm{H}_{2} \mathrm{O}\right)_{2}\right]^{2+}$ is 7.3 [29]. Thus, the low $\mathrm{pK}_{\mathrm{a}}$ value found for $\mathbf{1}$ is in line with a strong binding of the resulting hydroxide to two $\mathrm{Cu}$ ions and can be assigned to the formation of the $\mu-\mathrm{OH}$ species. As expected, the $\mathrm{pK}_{\mathrm{a}}$ value is lower than that of the analogous $\mathrm{Zn}$ complex $\left(\mathrm{pK}_{\mathrm{a}}=5.37\right)$ [12]. The electrochemical properties of the dicopper complex were investigated using cyclic voltammetry (CV). Fig. S3 shows the cyclovoltammogram of the complex in phosphate buffer displaying oxidation and reduction peaks at $-0.04 \mathrm{~V}$ and $-0.62 \mathrm{~V}$ (vs. $\mathrm{Ag} / \mathrm{AgCl}$ ), respectively. The redox process is irreversible which suggests a fast decomposition of the $\mathrm{Cu}^{\mathrm{I}}-\mathrm{Cu}^{\mathrm{I}}$ species. This has also been observed for analogous binuclear $\mathrm{Cu}$ (II) complexes where redox peaks have been assigned to a $\mathrm{Cu}$ centered two-electron reduction process $\mathrm{Cu}_{2}^{\mathrm{II}} \rightarrow \mathrm{Cu}_{2}^{\mathrm{I}}[30,31]$.

The X-ray structure of $\mathbf{2}$ is shown in Fig. 1, selected bond lengths and angles are listed in Table 1 . The asymmetric unit of the $\mathrm{Cu}$ complex contains two crystallographically independent complex cations, four perchlorate anions and five water molecules of crystallization. The two complex cations have very similar geometric parameters and exhibit the typical features of five-coordinate $\mathrm{Cu}$ complexes of triazacyclononane and its derivatives [32-34]. Each Cu center adopts a distorted square pyramidal coordination geometry with the bridgehead nitrogen, one of the secondary nitrogens, the bridging phenolate oxygen and the bridging hydroxo group defining the basal plane, while the apical site is occupied 


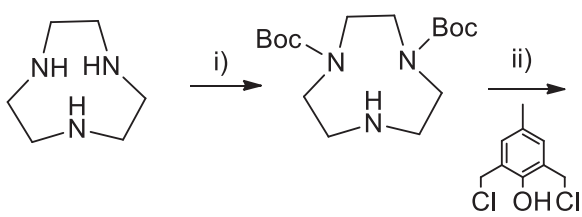<smiles>Cc1cc(CN2CCCN(C(=O)OC(C)(C)C)CC2)c(O)c(CN2CCN(C(=O)OC(C)(C)C)CCN(C(=O)c3ccccc3)CC2)c1</smiles><smiles>Cc1cc(CN2CCNCCNCC2)c(O)c(CN2CCNCCNCC2)c1</smiles>

bcmp

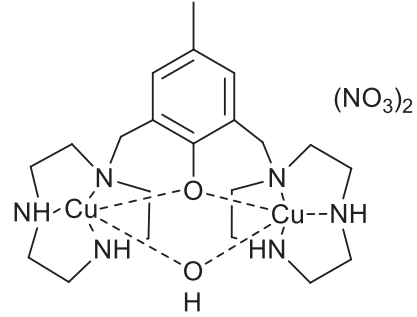

1

Chart 1. Synthetic route for the synthesis of the Cu complex 1: i) BOC-ON, $\mathrm{CHCl}_{3}$; ii) $\mathrm{THF} / \mathrm{CHCl}_{3}$; iii) $\mathrm{TFA} / \mathrm{CH}_{2} \mathrm{Cl}_{2} / \mathrm{Et}_{2} \mathrm{O}$; iv) $\mathrm{Cu}\left(\mathrm{NO}_{3}\right)_{2}$.

by the other secondary nitrogen. The four $\mathrm{Cu}$ ions lie $0.205(6)(\mathrm{Cu}(1))$, $0.197(5)(\mathrm{Cu}(2)), 0.180(6)(\mathrm{Cu}(3))$, and $0.198(6) \AA(\mathrm{Cu}(4))$ above their respective basal planes. The $\tau$ values which indicate the degree of trigonal distortion from an ideal square pyramidal coordination geometry range from 0.137 to 0.252 . According to the definition by Addison $(\tau=(\alpha-\beta) / 60$, where $\alpha$ and $\beta$ are the two largest bond angles) an ideal square pyramid has a $\tau$ value of 0 , while $\tau$ is 1 for a trigonal bipyramid [35]. As expected for $\mathrm{d}^{9} \mathrm{Cu}$ ions with square pyramidal coordination geometry, the $\mathrm{Cu}-\mathrm{N}$ bond distances are shorter for equatorial nitrogens (2.001 to $2.017 \AA$ ) than for the apical nitrogen (2.198 to $2.257 \AA$ ) [36,37] The apical nitrogens of the $\mathrm{Cu}$ ions are anti to each other. $\mathrm{The} \mathrm{Cu}_{2} \mathrm{O}_{2}$ units are planar (maximum deviation from the best weighted plane $0.005 \AA$ in cation 1 and $0.002 \AA$ in cation 2). The $\mathrm{Cu}_{2} \mathrm{O}_{2}$ plane and the bridging phenyl ring form a dihedral angle of 29.5(8) and 29.0(5) ${ }^{\circ}$ in cation 1 and 2 respectively.

\subsection{Biological studies}

\subsubsection{Cytotoxicity}

The antiproliferative effects of $\mathbf{1}$ were assessed on a panel of six human tumor cell lines including examples of human breast (MCF-7), cervical (A431), colorectal (HCT-15), pancreatic (BxPC3) and ovarian<smiles>O=[N+]([O-])c1ccc(OP2([O-])(Oc3ccc([N+](=O)[O-])cc3[N+](=O)[O-])C[C@H]3O[C@@H](O2)O3)c([N+](=O)[O-])c1</smiles>

Chart 2. Possible mechanism of action for the hydrolysis of BDNPP by complex $\mathbf{1}$.
(2008) cancers as well as melanoma. For comparison purposes, the cytotoxicity of cisplatin, the most widely used metal-based anticancer drug, was evaluated under the same experimental conditions. $\mathrm{IC}_{50}$ values, calculated from the dose-survival curves obtained after $72 \mathrm{~h}$ of drug treatment from the MTT test, are shown in Table S2. While the cytotoxic activity was considerably lower than that of cisplatin against MCF-7, A431, HCT-15, A549 and 2008 tumor cell lines, the dimetallic $\mathrm{Cu}$ (II) complex retained a significant in vitro antitumor activity against pancreatic cancer cells. Tested on a panel of five different pancreatic cancer cell lines (Table 2), compound $\mathbf{1}$ showed a cell killing activity that was similar or even better than that exerted by cisplatin. Interestingly, the greater efficacy was detected in metastatic site derived pancreatic Capan-1 and AsPC-1 cancer cell, on the other hand, the cytotoxic potency was about two times lower than that of cisplatin against p53 null Mia PaCa-2 cells.

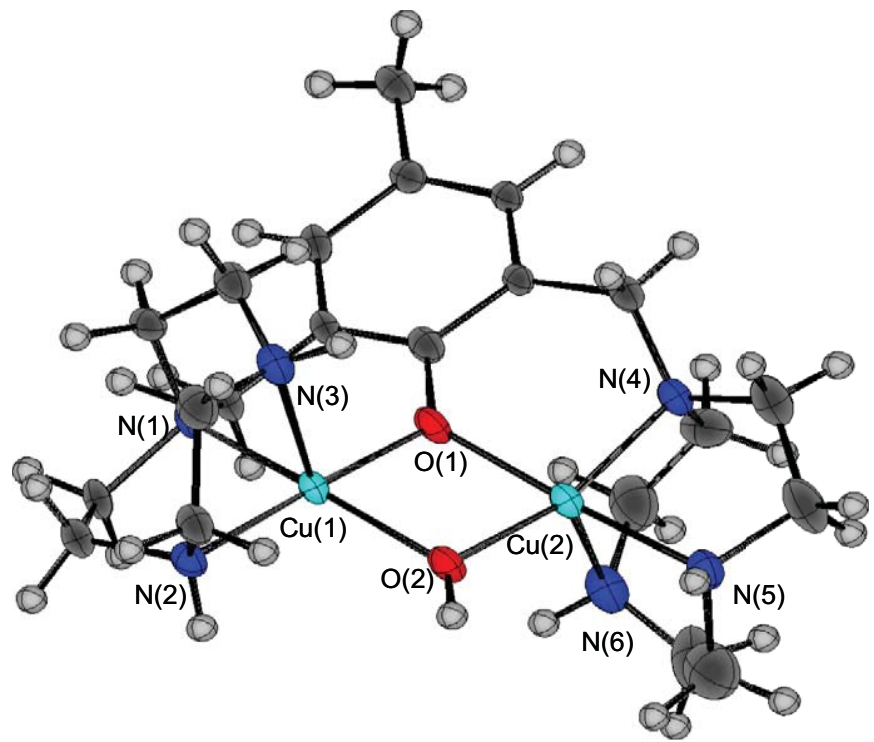

Fig. 1. View of the cation of $\left[\mathrm{Cu}_{2}\{\mathrm{bcmp}(-\mathrm{H})\}(\mu-\mathrm{OH})\right]\left(\mathrm{ClO}_{4}\right)_{2} \cdot 2.5 \mathrm{H}_{2} \mathrm{O}(2)$ with the atom numbering scheme. For the sake of clarity, only one of the two crystallographically independent complex cations is shown. Thermal ellipsoids are drawn at the $40 \%$ level. 
Table 1

Selected bond lengths $[\AA]$, angles $\left[{ }^{\circ}\right]$ and hydrogen bonding interactions in compound 2.

\begin{tabular}{lrlr}
\hline $\mathrm{Cu}(1)-\mathrm{N}(1)$ & $2.009(6)$ & $\mathrm{Cu}(3)-\mathrm{N}\left(1^{\prime}\right)$ & \multicolumn{1}{c}{$2.035(6)$} \\
\hline $\mathrm{Cu}(1)-\mathrm{N}(2)$ & $2.015(6)$ & $\mathrm{Cu}(3)-\mathrm{N}\left(2^{\prime}\right)$ & $2.223(7)$ \\
$\mathrm{Cu}(1)-\mathrm{N}(3)$ & $2.198(8)$ & $\mathrm{Cu}(3)-\mathrm{N}\left(3^{\prime}\right)$ & $2.013(6)$ \\
$\mathrm{Cu}(1)-\mathrm{O}(1)$ & $1.933(5)$ & $\mathrm{Cu}(3)-\mathrm{O}\left(1^{\prime}\right)$ & $1.934(5)$ \\
$\mathrm{Cu}(1)-\mathrm{O}(2)$ & $1.980(5)$ & $\mathrm{Cu}(3)-\mathrm{Cl}\left(1^{\prime}\right)$ & $1.944(5)$ \\
$\mathrm{Cu}(2)-\mathrm{N}(4)$ & $2.017(6)$ & $\mathrm{Cu}(4)-\mathrm{N}\left(4^{\prime}\right)$ & $2.044(6)$ \\
$\mathrm{Cu}(2)-\mathrm{N}(5)$ & $2.015(6)$ & $\mathrm{Cu}(4)-\mathrm{N}\left(5^{\prime}\right)$ & $2.001(6)$ \\
$\mathrm{Cu}(2)-\mathrm{N}(6)$ & $2.257(7)$ & $\mathrm{Cu}(4)-\mathrm{N}\left(6^{\prime}\right)$ & $2.232(6)$ \\
$\mathrm{Cu}(2)-\mathrm{O}(1)$ & $1.922(5)$ & $\mathrm{Cu}(4)-\mathrm{O}\left(1^{\prime}\right)$ & $1.941(5)$ \\
$\mathrm{Cu}(2)-\mathrm{O}(2)$ & $1.961(5)$ & $\mathrm{Cu}(4)-\mathrm{O}\left(2^{\prime}\right)$ & $1.946(5)$ \\
$\mathrm{Cu}(1) \cdots \mathrm{Cu}(2)$ & $3.015(1)$ & $\mathrm{Cu}(3) \cdots \mathrm{Cu}(4)$ & $2.981(1)$ \\
$\mathrm{N}(1)-\mathrm{Cu}(1)-\mathrm{N}(2)$ & $86.5(3)$ & $\mathrm{N}\left(1^{\prime}\right)-\mathrm{Cu}(3)-\mathrm{N}\left(2^{\prime}\right)$ & $84.0(3)$ \\
$\mathrm{N}(1)-\mathrm{Cu}(1)-\mathrm{N}(3)$ & $85.4(3)$ & $\mathrm{N}\left(1^{\prime}\right)-\mathrm{Cu}(3)-\mathrm{N}\left(3^{\prime}\right)$ & $86.9(3)$ \\
$\mathrm{N}(2)-\mathrm{Cu}(1)-\mathrm{N}(3)$ & $84.3(3)$ & $\mathrm{N}\left(2^{\prime}\right)-\mathrm{Cu}(3)-\mathrm{N}\left(3^{\prime}\right)$ & $83.3(3)$ \\
$\mathrm{N}(1)-\mathrm{Cu}(1)-\mathrm{O}(2)$ & $161.1(2)$ & $\mathrm{N}\left(1^{\prime}\right)-\mathrm{Cu}(3)-\mathrm{O}\left(2^{\prime}\right)$ & $161.4(2)$ \\
$\mathrm{N}(2)-\mathrm{Cu}(1)-\mathrm{O}(1)$ & $173.1(3)$ & $\mathrm{N}\left(3^{\prime}\right)-\mathrm{Cu}(3)-\mathrm{O}\left(1^{\prime}\right)$ & $176.5(3)$ \\
$\mathrm{N}(4)-\mathrm{Cu}(2)-\mathrm{N}(5)$ & $86.5(2)$ & $\mathrm{N}\left(4^{\prime}\right)-\mathrm{Cu}(4)-\mathrm{N}\left(5^{\prime}\right)$ & $86.7(2)$ \\
$\mathrm{N}(4)-\mathrm{Cu}(2)-\mathrm{N}(6)$ & $83.6(2)$ & $\mathrm{N}\left(4^{\prime}\right)-\mathrm{Cu}(4)-\mathrm{N}\left(6^{\prime}\right)$ & $83.2(2)$ \\
$\mathrm{N}(5)-\mathrm{Cu}(2)-\mathrm{N}(6)$ & $82.0(2)$ & $\mathrm{N}\left(5^{\prime}\right)-\mathrm{Cu}(4)-\mathrm{N}\left(6^{\prime}\right)$ & $82.8(2)$ \\
$\mathrm{N}(4)-\mathrm{Cu}(2)-\mathrm{O}(2)$ & $166.7(2)$ & $\mathrm{N}\left(4^{\prime}\right)-\mathrm{Cu}(4)-\mathrm{O}\left(2^{\prime}\right)$ & $162.2(2)$ \\
$\mathrm{N}(5)-\mathrm{Cu}(2)-\mathrm{O}(1)$ & $176.4(3)$ & $\mathrm{N}\left(5^{\prime}\right)-\mathrm{Cu}(4)-\mathrm{O}\left(1^{\prime}\right)$ & $172.9(3)$ \\
$\mathrm{Cu}(1)-\mathrm{O}(1)-\mathrm{Cu}(2)$ & $102.9(2)$ & $\mathrm{Cu}(3)-\mathrm{O}\left(1^{\prime}\right)-\mathrm{Cu}(4)$ & $100.6(2)$ \\
$\mathrm{Cu}(1)-\mathrm{O}(2)-\mathrm{Cu}(2)$ & $99.8(2)$ & $\mathrm{Cu}(3)-\mathrm{O}\left(2^{\prime}\right)-\mathrm{Cu}(4)$ & $100.0(2)$ \\
\hline & & &
\end{tabular}

Complex 1 was also tested against a human non-tumor cell line, namely human embryonic kidney HEK293 cells (human non-cancerous cells in rapid proliferation). Notably, against noncancerous cells, complex 1 elicited a cytotoxic activity approximately 5 -fold lower than that recorded after cisplatin treatment (Table 2). The selectivity index value, (i.e. the average $\mathrm{IC}_{50}$ towards normal HEK293 cells divided by the average $\mathrm{IC}_{50}$ towards all malignant cells included in the panel) calculated for $\mathbf{1}$ was approximately 1.5 -fold higher than that obtained with the reference metallodrug, thus suggesting a noticeable preferential cytotoxicity of $\mathbf{1}$ versus neoplastic cells.

\subsubsection{DNA damage}

The ability of $\mathbf{1}$ to cause DNA damage in Capan-1 cells was investigated. After treatment with increasing concentrations of $\mathbf{1}$ for 6 and $12 \mathrm{~h}$, evidence for cleavage of cellular DNA was obtained by alkaline single cell gel electrophoresis (Fig. 2). Cells treated with $\mathbf{1}$ displayed a statistically significant increase in electrophoretic migration of the DNA fragments, evidenced by well-formed comets. As evident form the comet tail lengths (length of DNA migration), which are directly related to the DNA fragment size, complex $\mathbf{1}$ caused a marked time- and dosedependent increase in comet tail lengths confirming its ability to cleave cellular DNA.

\subsubsection{Mechanism of cell death induction}

Cell death induction in Capan-1 pancreatic cancer cells treated for 48 and $72 \mathrm{~h}$ with $\mathrm{IC}_{50}$ doses of complex $\mathbf{1}$ was also studied by monitoring the morphological changes of Hoechst 33258-stained cells via fluorescent microscopy analysis (Fig. 3A). Compared to control cells, 1-treated

Table 2

$\mathrm{IC}_{50}$ values $(\mu \mathrm{M})$ of $\mathbf{1}$ and cisplatin for pancreatic cancer cell lines. Cells $\left(3-8 \times 10^{4} \cdot \mathrm{mL}^{-1}\right)$ were treated for $72 \mathrm{~h}$ with increasing concentrations of tested compounds. Cell viability was evaluated by means of MTT test. $\mathrm{IC}_{50}$ values were calculated by the dose-response curves by means of four parameter logistic model $(\mathrm{p}<0.05)$. SD = standard deviation.

\begin{tabular}{llr}
\hline $\mathrm{IC}_{50}(\mu \mathrm{M}) \pm \mathrm{SD}$ & \\
\hline Compound & 1 & \multicolumn{1}{c}{ Cisplatin } \\
\hline MIA PaCa-2 & $30.43 \pm 3.15$ & $16.76 \pm 1.89$ \\
Panc-1 & $21.19 \pm 4.25$ & $8.54 \pm 3.54$ \\
Capan-1 & $11.67 \pm 6.52$ & $13.17 \pm 0.97$ \\
BxPC3 & $18.77 \pm 2.24$ & $11.13 \pm 2.36$ \\
AsPC-1 & $14.73 \pm 2.52$ & $15.11 \pm 1.94$ \\
HEK293 & $89.76 \pm 4.65$ & $17.62 \pm 2.87$ \\
\hline
\end{tabular}

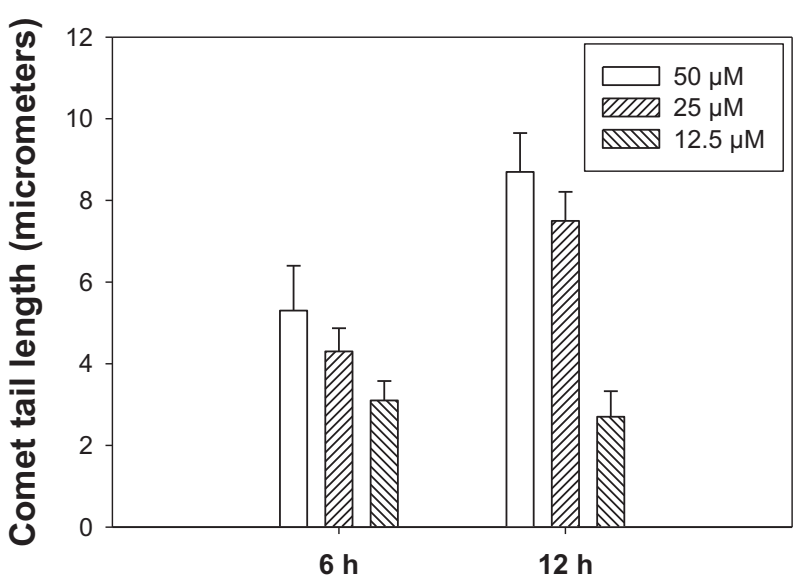

Fig. 2. Single cell gel electrophoresis. Capan-1 cells were treated for different incubation times (6 or $12 \mathrm{~h}$ ) with increasing concentration of $\mathbf{1}$ and then processed for comet assay. The comet tail length was calculated from the center of the cell and measured in micrometers with CellF software. The error bars indicate the S.D.

cells presented brightly stained nuclei and morphological features typical of apoptosis, such as chromatin condensation and fragmentation, thus confirming the induction of an apoptotic cell death.

It has been shown that in response to treatment with a variety of DNA-damaging agents an induction of tumor suppressor p53 occurs. The activation of $\mathrm{p} 53$ which plays a pro-apoptotic role by inducing and downregulating many fundamental cell death effectors, ultimately leads to apoptotic cell death [38]. By taking into consideration that the cytotoxic potency of $\mathbf{1}$ is about two times lower against $\mathrm{p} 53$ null pancreatic Mia PaCa-2 cells than towards pancreatic p53 wild-type cells (BxPC3, AsPC-1, Capan-1 and PANC-1), we studied the effect of $\mathbf{1}$ on p53. Notably, complex 1 provoked a concentration-dependent increase in p53 activity (Fig. 3B). Taken together, cytotoxicity and p53 results indicate that this complex can activate apoptotic cell death pathways by a mechanism that is p53-dependent. Thus, cancer cell sensitivity to the studied Cu complex strongly depends on the p53 status.

\subsection{DNA cleavage and phosphate diester hydrolysis}

To gain insight into the molecular interactions of complex $\mathbf{1}$ with DNA, we performed in vitro experiments on supercoiled (SC) plasmid pUC19 DNA. The cleavage ability of the $\mathrm{Cu}$ complex was measured by monitoring the conversion of SC-DNA (form I) into the nicked-circular form (NC, form II) using gel electrophoresis. SC pUC19 DNA $(1 \mu \mathrm{g} / \mathrm{mL})$ was incubated with increasing complex concentrations (range 5-50 $\mu \mathrm{M}$ ) for $3 \mathrm{~h}$. Fig. 4 shows representative gel electrophoresis patterns resulting from incubation of SC-DNA with complex $\mathbf{1}$. Treatment with complex 1 resulted in a concentration-dependent pUC19 cleavage. Notably, at $25 \mu \mathrm{M}$ concentration (lane 3), complex 1 was able to convert SC-DNA into the NC form and at $50 \mu \mathrm{M}$ concentration (lane 4) complete nicking of DNA was observed as evidenced by the absence of the form I. It is worthy of note that no external reducing agent was added. This does not necessarily suggest a hydrolytic cleavage mechanism, as several self-activating oxidative $\mathrm{Cu}$ metallonucleases have been described [39-45]. In fact, Cu complexes that actually cleave DNA by a hydrolytic mechanism are less numerous [46-48]. In order to distinguish between an oxidative and hydrolytic mechanism, ROS scavengers specific for singlet oxygen (DABCO), hydroxyl radical (DMSO) or hydrogen peroxide (DMTU), have been added. The nuclease activity of complex 1 (Fig. S4) was not influenced by the addition of these scavengers, thus suggesting that DNA cleavage is hydrolytic. Notwithstanding, we thought it of interest to explore the potential of $\mathbf{1}$ to mediate phosphate ester hydrolysis using BDNPP (bis(2,4-dinitrophenyl) phosphate) which is a widely used model for the phosphodiester linkages in DNA. 


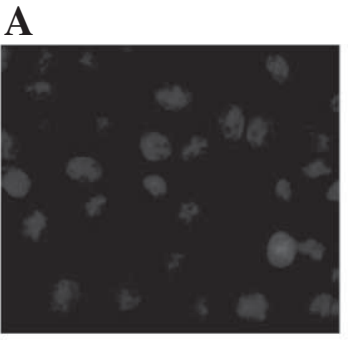

Control

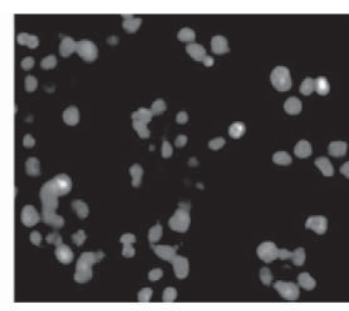

$1,48 \mathrm{~h}$

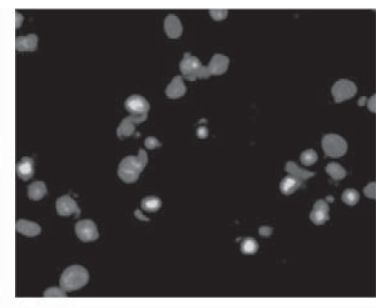

$1,72 \mathrm{~h}$

B

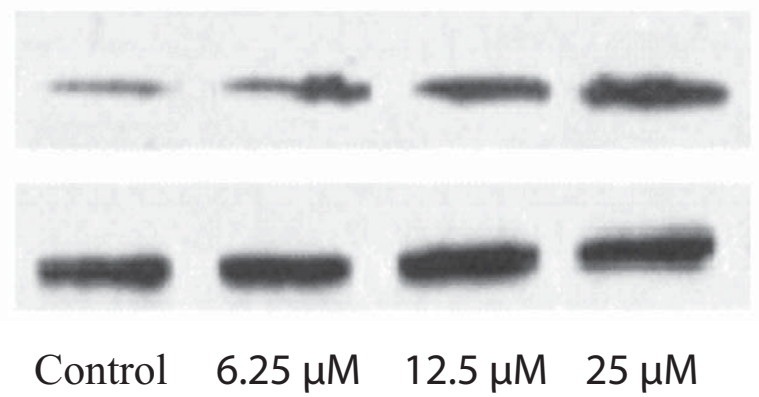

Fig. 3. Apoptosis induction and p53 activation. A. Hoechst 33258 staining. Capan-1 cells were incubated for 48 and $72 \mathrm{~h}$ with IC $\mathrm{C}_{50}$ doses of complex $\mathbf{1}$ and stained with the fluorescent dye Hoechst 33258. B. Capan-1 cells were treated with increasing concentrations of $\mathbf{1}$ for 48 h. The amount of p53 was detected by Western blotting analysis as described in the Experimental Section.

1-mediated BDNPP hydrolysis was monitored by following the increase in the visible absorbance at $400 \mathrm{~nm}$ because of the release of 2,4-dinitrophenolate. The dependence of the reaction rate of BDNPP cleavage on the $\mathrm{pH}$ value in the presence of $\mathbf{1}$ was studied over the $\mathrm{pH}$ range 3.5-12.0. The plot of the pseudo-first-order rate constants vs. $\mathrm{pH}$ revealed a sigmoidal curve (Fig. 5). Fitting the data to

$\mathrm{k}_{\mathrm{obs}}=\left(\mathrm{k}_{\mathrm{H} 2 \mathrm{O}}\left[\mathrm{H}^{+}\right]+\mathrm{k}_{\mathrm{OH}} \mathrm{K}_{\mathrm{a}}\right) /\left(\mathrm{K}_{\mathrm{a}}+\left[\mathrm{H}^{+}\right]\right)$

gave $\mathrm{k}_{\mathrm{H} 2 \mathrm{O}}=5.75 \times 10^{-6} \mathrm{~s}^{-1}, \mathrm{k}_{\mathrm{OH}}=6.0 \times 10^{-4} \mathrm{~s}^{-1}$ and a kinetic $\mathrm{pK}_{\mathrm{a}}$ value of $\mathrm{pH}$ 6.97. The kinetic $\mathrm{pK}_{\mathrm{a}}$ value is 2.3 units higher than the thermodynamic $\mathrm{pK}_{\mathrm{a}}$ value for the bridging water in $\left[\mathrm{Cu}_{2}\{\mathrm{bcmp}(-\mathrm{H})\}(\mu-\right.$ $\left.\left.\mathrm{H}_{2} \mathrm{O}\right)\right]^{3+}$ determined by potentiometric titration $\left(\mathrm{pK}_{\mathrm{a}}=4.69\right)$. This might be explained by a weakening of one of the $\mu-\mathrm{OH}-\mathrm{Cu}$ bonds on substrate binding (Chart 2). The hydroxide in the catalytically active species can act as a nucleophile or a general base. To gain more insight into the reaction mechanism, the solvent deuterium isotope effect $\mathrm{k}_{\mathrm{H}} / \mathrm{k}_{\mathrm{D}}$ was measured. The solvent deuterium isotope effect is the classical method for distinguishing between a nucleophilic and a general base mechanism. Generally, a $\mathrm{k}_{\mathrm{H}} / \mathrm{k}_{\mathrm{D}}$ value ranging from 0.8 to 1.5 indicates a nucleophilic mechanism for phosphate ester hydrolysis, where no proton transfer is involved in the rate-determining step, while a $\mathrm{k}_{\mathrm{H}} / \mathrm{k}_{\mathrm{D}}$ value greater than 2 supports a general base mechanism, where $\mathrm{M}-\mathrm{OH}$ deprotonates an external nucleophile [49]. The average $\mathrm{k}_{\mathrm{H}} / \mathrm{k}_{\mathrm{D}}$ value obtained at different $\mathrm{pL}$ values $(\mathrm{L}=\mathrm{H}, \mathrm{D})$ for the hydrolysis of

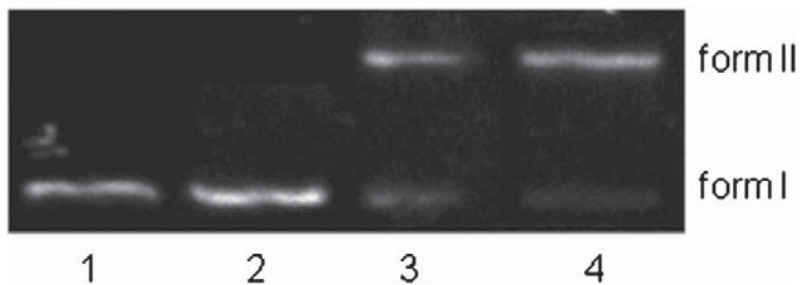

Fig. 4. DNA cleavage. Agarose gel electrophoresis patterns of SC pUC19 DNA incubated with complex 1 in Tris buffer at $37^{\circ} \mathrm{C}$ for $3 \mathrm{~h}$. Lane 1: DNA control; lane 2: DNA $+5 \mu \mathrm{M}$ 1; lane 3: DNA + $25 \mu \mathrm{M} 1$; lane 4: DNA + $50 \mu \mathrm{M} 1$.
BDNPP in the presence of $\mathbf{1}$ is 0.98 (Table S3) suggesting a direct nucleophilic attack of the $\mathrm{OH}$ group to the phosphorous (Chart 2). This agrees with work reported by Neves and co-workers who showed that the hydrolysis of BDNPP by similar binuclear complexes of type $\mathrm{Fe}^{\mathrm{III}}(\mu-\mathrm{OH}) \mathrm{M}^{\mathrm{II}}$ and $\mathrm{Fe}^{\mathrm{III}}\left(\mu-\mathrm{CH}_{3} \mathrm{COO}\right)_{2} \mathrm{M}^{\mathrm{II}}(\mathrm{M}=\mathrm{Zn}, \mathrm{Cu}, \mathrm{Mn}, \mathrm{Fe})$ proceeds via a mechanism that involves intramolecular attack of a terminally $\mathrm{Fe}^{\mathrm{III}}$-bound hydroxide [50-53]. Neves et al. concluded that $\mu-\mathrm{OH}$ was a poorer nucleophile than a terminal $\mathrm{OH}$. The dependence of the hydrolysis rate on the concentration of the Cu complex ( $\mathrm{pH} 8.0,40^{\circ} \mathrm{C}$, Fig. S5) shows a linear increase of the hydrolysis rate in the $0.5-2.5 \mathrm{mM}$ concentration range for $\mathbf{1}$. Higher concentrations could not be analysed, as the complex precipitated out of solution. A linear fit of the data gave an apparent second-order rate constant of $0.047 \mathrm{M} \mathrm{s}^{-1}$. This agrees favorably with the apparent second order rate constant of $0.021 \mathrm{M} \mathrm{s}^{-1}$ reported for the closely related dinuclear $\mathrm{Cu}^{\mathrm{II}}(\mu-\mathrm{OH}) \mathrm{Cu}^{\mathrm{II}}$ complex with the Schiff base ligand 6-amino-6methylperhydro-1,4-diazepine [54,55]. However, DFT calculations for

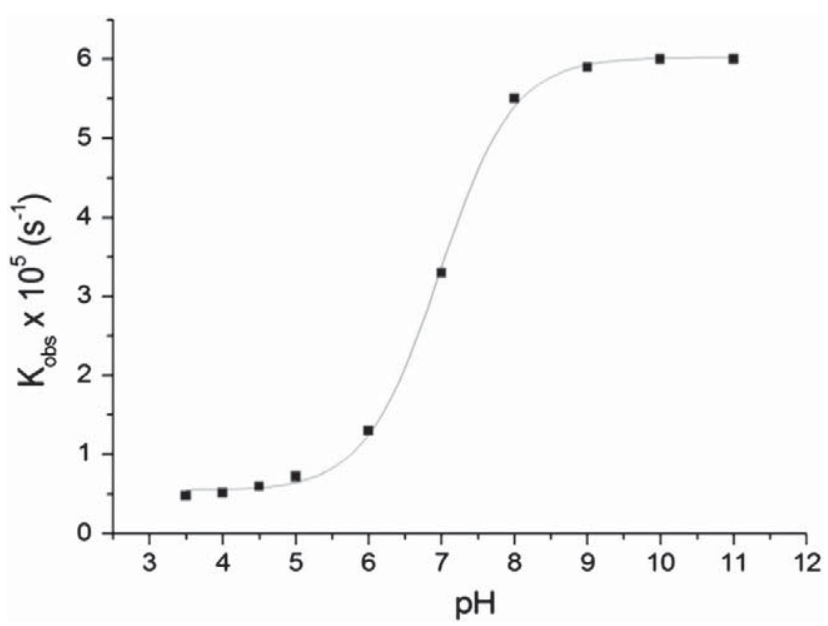

Fig. 5. Rate-pH profile for the cleavage of $\operatorname{BDNPP}\left(5 \times 10^{-5} \mathrm{M}\right)$ in the presence of $\mathbf{1}(1 \mathrm{mM})$ at $40{ }^{\circ} \mathrm{C}$. [buffer] $=50 \mathrm{mM}$ (buffer $=$ PIPBS (pH 3.5-5), MES (pH 5-6.7), HEPES (pH 6.8$8.5)$, and CHES ( $\mathrm{pH} 8.5-9.5) ; I=0.1 \mathrm{M}\left(\mathrm{KNO}_{3}\right)$. 
this complex suggested a mechanism that involves nucleophilic attack by the bridging hydroxide of the Schiff base complex.

\section{Conclusions}

$\left[\mathrm{Cu}_{2}\{\mathrm{bcmp}(-\mathrm{H})\}(\mu-\mathrm{OH})\right]\left(\mathrm{NO}_{3}\right)_{2}$ is a new dicopper(II) complex which shows interesting cytotoxic activity against pancreatic cancer cell lines and selectivity for cancer cells over non-cancer cells. The $\mathrm{Cu}$ complex can interact with cellular DNA and induce apoptotic cell death via the p53-dependent pathway. Furthermore, the complex promotes the hydrolysis of the DNA model BDNPP by a mechanism involving nucleophilic attack by $\mathrm{Cu}-\mathrm{OH}$ and converts SC-DNA into the nicked form in the absence of external reductants. Taken together, the reported results herein confirm that the dinuclear bis(triazacyclonane) copper complex represents an attractive "self-activating" metallonuclease. Moreover, the remarkable results obtained in terms of selectivity against Capan-1 pancreatic cancer cell call for further studies focused on characterizing the antitumor efficacy against this cancer type.

\section{Abbreviations}

bcmp 2,6-bis(1,4,7-triazacyclonon-1-ylmethyl)-4-methylphenol

BDNPP bis(2,4-dinitrophenyl) phosphate

CHES N-cyclohexyl-2-aminoethanesulfonic acid

DABCO 1,4-diazabicyclo[2.2.2] octane

DMSO dimethylsulfoxide

DMTU dimethylthiourea

EDTA ethylenediaminetetraacetic acid

ESI Electrospray ionization

HEPES 4-(2-hydroxyethyl)-1-piperazineethanesulfonic acid

MES 2-( $N$-morpholino)ethanesulfonic acid

PBS phosphate buffered saline

PIPBS piperazine- $N, N$-bis(4-butanesulfonic acid)

TBE tris/borate/EDTA

\section{Acknowledgments}

Financial supports from the European Commission and Science Foundation Ireland (Marie Curie FP7-IEF to D.M., Stokes Lectureship to A.E., grant no. 07/SK/B1225b) and from the University of Padova (Progetto di Ateneo CPDA121973/12) are gratefully acknowledged. We thank Dr. Paul Kavanagh for the electrochemical measurements. Prof. Michael J. Hynes is thanked for the calculation of the deprotonation constant from the titration data.

\section{Appendix A. Supplementary data}

Crystallographic data for $\mathbf{2}$ have been deposited with the Cambridge Crystallographic Data Centre, CCDC no. 920701. Copies of the data may be obtained free of charge from The Director, CCDC, 12 Union Road, Cambridge CB2 1EZ, UK (fax:+44-1223-336033; e-mail: deposit@ccdc.cam. ac.uk or www: http://www.ccdc.cam.ac.uk). Supplementary data to this article can be found online at http://dx.doi.org/10.1016/j.jinorgbio.2015. 01.013. These data include cytotoxicity data of $\mathbf{1}$, the ESI MS spectrum of $\mathbf{1}$, potentiometric titration data of $\mathbf{1}$, the cyclovoltammogram of $\mathbf{1}$, gel electrophoresis patterns of radical scavenger experiments, the rateconcentration profile and $\mathrm{k}_{\mathrm{H}} / \mathrm{k}_{\mathrm{D}}$ values for 1 -mediated BDNPP hydrolysis.

\section{References}

[1] H.B. Kraatz, N. Metzler-Nolte, Concepts and Models in Bioinorganic Chemistry, Wiley-VCH, Weinheim, Germany, 2006

[2] S.J. Lippard, J.M. Berg, Principles of Bioinorganic Chemistry, University Science Books, Mill Valley, CA, 1994.
[3] J.J.R. Frausto da Silva, R.J.P. Williams, The Biological Chemistry of the Elements, Clarendon, Oxford, U. K., 1991

[4] C. Santini, M. Pellei, V. Gandin, M. Porchia, F. Tisato, C. Marzano, Chem. Rev. 114 (2014) 815-862.

[5] F. Tisato, C. Marzano, M. Porchia, M. Pellei, C. Santini, Med. Res. Rev. 30 (2010) 708-749.

[6] C. Marzano, M. Pellei, F. Tisato, C. Santini, Anti Cancer Agents Med. Chem. 9 (2009) $185-211$.

[7] C. Wende, C. Lüdtke, N. Kulak, Eur. J. Inorg. Chem. 2597-2612 (2014).

[8] K. Suntharalingam, D.J. Hunt, A.A. Duarte, A.J.P. White, D.J. Mann, R. Vilar, Chem. Eur J. 18 (2012) 15133-15141

[9] F. Mancin, P. Scrimin, P. Tecilla, Chem. Commun. 48 (2012) 5545-5559.

[10] C.A. Bunton, S.J. Farber, J. Org. Chem. 34 (1969) 767-772.

[11] H.S. Chang, H. Diril, M.J. Nilges, X. Zhang, J.A. Potenza, H.J. Schugar, D.N. Hendrickson, S.S. Isied, J. Am. Chem. Soc. 110 (1988) 625-627.

[12] D. Montagner, V. Gandin, C. Marzano, A. Erxleben, Eur. J. Inorg. Chem. 25 (2014) 4084-4092.

[13] P. Gans, A. Sabatini, A. Vacca, Talanta 43 (1996) 1739-1753.

[14] A.E. Martell, R.M. Smith, Critical Stability Constants, Plenum Press, New York, 1977.

[15] P.K. Glasoe, F.A. Long, J. Phys. Chem. 64 (1960) 188-190.

[16] K. Mikkelse, S.O. Nielsen, J. Phys. Chem. 64 (1960) 632-637.

[17] CrysAlisPro, Oxford Diffraction Ltd., Version 1.171.33.31, 2009. (release 08-01-2009 CrysAlis171.NET)

[18] G.M. Sheldrick, SHELXS-97, Program for Crystal Structure Solution, University of Göttingen, Germany, 1997.

[19] G.M. Sheldrick, SHELXL-97, Program for Crystal Structure Refinement, University of Göttingen, Germany, 1997

[20] G.M. Sheldrick, SHELXTL-PLUS (VMS), Siemens Analytical X-ray Instruments, Inc Madison, WI, 1990.

[21] P. McArdle, K. Gilligan, D. Cunningham, R. Dark, M. Mahon, CrystEngComm 6 (2004) 303-309.

[22] Y. Le Page, J. Appl. Crystallogr. 20 (1987) 264-269.

[23] Y. Le Page, J. Appl. Crystallogr. 21 (1988) 983-984.

[24] H.D. Flack, Acta Crystallogr. A39 (1983) 876-881.

[25] P. McArdle, PC Windows Version, J. Appl. Crystallogr. 28 (1995) 65-65.

[26] M.C. Alley, D.A. Scudiero, A. Monks, M.L. Hursey, M.J. Czerwinski, D. Fine, B.J. Abbott, J.G. Mayo, R.H. Shoemaker, M.R. Boyd, Cancer Res. 48 (1988) 589-601.

[27] R. Yang, L.J. Zompa, Inorg. Chem. 15 (1976) 1499-1502.

[28] M.J. Young, J. Chin, J. Am. Chem. Soc. 117 (1995) 10577-10578.

[29] K.A. Deal, J.N. Burstyn, Inorg. Chem. 35 (1996) 2792-2798

[30] M. Kato, T. Tanase, M. Mikuriya, Inorg. Chem. 45 (2006) 2925-2941.

[31] S. Torelli, C. Belle, I. Gautier-Luneau, J.L. Pierre, E. Saint-Aman, J.M. Latour, L. Le Pape, D. Luneau, Inorg. Chem. 39 (2000) 3526-3536.

[32] F.H. Fry, L. Spiccia, P. Jensen, B. Moubaraki, K.S. Murray, E.R.T. Tiekink, Inorg. Chem 42 (2003) 5594-5603.

[33] S.J. Brudenell, L. Spiccia, A.M. Bond, P. Comba, D.C.R. Hockless, Inorg. Chem. 37 (1998) 3705-3713.

[34] B. Graham, G.D. Fallon, M.T.W. Hearn, D.C.R. Hockless, G. Lazarev, L. Spiccia, Inorg. Chem. 36 (1997) 6366-6373.

[35] A.W. Addison, T.N. Rao, J. Reedijk, J. van Rijn, G.C.J. Verschoor, Chem. Soc., Dalton Trans. (1984) 1349-1354.

[36] R.D. Bereman, M.R. Churchill, P.M. Schaber, M.E. Winkler, Inorg. Chem. 18 (1979) 3123-3128.

[37] W.F. Schwindinger, T.G. Fawcett, R.A. Lalancette, J.A. Potenza, H. Schugar, Inorg. Chem. 19 (1980) 1379-1385

[38] Y. Sedletska, M.-J. Giraud-Panis, J.C. Malinge, Curr. Med. Chem. Anticancer Agents 5 (2005) 251-265.

[39] P.U. Maheswari, S. Roy, H. den Dulk, S. Barends, G. van Wezel, B. Kozlevcar, P. Gamez, J. Reedijk, J. Am. Chem. Soc. 128 (2006) 710-711.

[40] P.U. Maheswari, M. van der Ster, S. Smulders, S. Barends, G.P. van Wezel, C. Massera, S. Roy, H. den Dulk, P. Gamez, J. Reedijk, Inorg. Chem. 47 (2008) 3719-3727.

[41] A. Kellett, M. O'Connor, M. McCann, M. McNamara, P. Lynch, G. Rosair, V. McKee, B. Creaven, M. Walsh, S. McClean, A. Foltyn, D. O'Shea, O. Howe, M. Devereux, Dalton Trans. 40 (2011) 1024-1027.

[42] A. Prisecaru, M. Devereux, N. Barron, M. McCann, J. Colleran, A. Casey, V. McKee A. Kellett, Chem. Commun. 48 (2012) 6906-6908

[43] A. Kellett, O. Howe, M. O'Connor, M. McCann, B.S. Creaven, S. McClean, A. Foltyn-Arfa Kia, A. Casey, M. Devereux, Free Radic. Biol. Med. 53 (2012) 564-576.

[44] B. Coyle, P. Kinsella, M. McCann, M. Devereux, R. O'Connor, M. Clynes, K. Kavanagh, Toxicol. in Vitro 18 (2004) 63-70.

[45] R. Loganathan, S. Ramakrishnan, E. Suresh, A. Riyasdeen, M.A. Akbarsha, M. Palaniandavar, Inorg. Chem. 51 (2012) 5512-5532.

[46] S. Anbu, M. Kandaswamy, S. Kamalraj, J. Muthumarry, B. Varghese, Dalton Trans. 40 (2011) 7310-7318.

[47] M. Roy, S. Dhar, B. Maity, A.R. Chakravarty, Inorg. Chim. Acta 375 (2011) 173-180.

[48] M.S. Deshpande, A.S. Kumbhar, C. Näther, Dalton Trans. 39 (2010) 9146-9152.

[49] V. Gold, Advances in Physical Organic Chemistry; Ed, Academic Press, New York, 1967.

[50] A. Neves, M. Lanznaster, A.J. Bortoluzzi, R.A. Peralta, A. Casellato, E.E. Castellano, P. Herrald, M.J. Riley, G. Schenk, J. Am. Chem. Soc. 129 (2007) 7486-7487.

[51] M. Lanznaster, A. Neves, A.J. Bortoluzzi, V.V.E. Aires, B. Szpoganicz, H. Terenzi, P. Cardoso Severino, J.M. Fuller, S.C. Drew, L.R. Gahan, G.R. Hanson, M.J. Riley, G. Schenk, J. Biol. Inorg. Chem. 10 (2005) 319-332.

[52] C. Piovezan, R. Jovito, A.J. Bortoluzzi, H. Terenzi, F.L. Fischer, P.C. Severino, C.T. Pich, G.G. Azzolini, R.A. Peralta, L.M. Rossi, A. Neves, Inorg. Chem. 49 (2010) 2580-2582

[53] P. Karsten, A. Neves, A.J. Bortoluzzi, M. Lanznaster, V. Drago, Inorg. Chem. 41 (2002) 4624-4626.

[54] N.A. Rey, A. Neves, A.J. Bortuluzzi, C.T. Pich, H. Terenzi, Inorg. Chem. 46 (2007) 348-350.

[55] N.A. Rey, A. Neves, W.B. De Almeida, H.F. Dos Santos, A.S. Costa, Int. J. Quant. Chem. 110 (2010) 1432-1442. 